\title{
Evaluation model: A performance appraisal model for certified lecturers
}

\author{
Dyah Ayu Puri Palupi ${ }^{1, *}$, Mardanung Patmo Cahjono ${ }^{1, *}$, and Kristyana Dananti ${ }^{1}$ \\ ${ }^{1}$ Universitas Kristen Surakarta, Jl. R.W. Monginsidi No. 36-38, Solo, Indonesia
}

\begin{abstract}
This study aims to develop lecturer performance appraisal model using web-based Integrated Evaluation Model (IEM). The object of this study is certified lecturers in Indonesia, by applying this model, the certification compensation given by the government is really used to enhance lecturer's performance. It is expected that the results of this study can be an important research that produces effective and efficient software to evaluate the lecturers' performance nationally because it involves a 360 degree assessment. We have done some activities to develop the prototype software application of Integrated Evaluation Model (IEM) for assessing the certified lecturer's performance. They are 1) preparing the questionnaire indicator for the 360 degree performance appraisal, 2) conduct the program test on the certified lecturer. In this phase, certified lecturers, superior, and students also conduct assessment on certified lecturers through IEM software, 3) conduct Focus Group Discussion (FGD) to gain evaluation and feedback on the effectiveness of the IEM application program. FGD results provide a valuable contribution to the preparation of IEM program design. And the IEM software produced in this research has accommodated all of the results of FGD activities. IEM complements the prior certified lecturer performance appraisal with 360 degrees performance appraisal.

Keywords: certified lecturers, 360 degrees performance appraisal, IEM
\end{abstract}

\section{Introduction}

The quality of education plays an important role in a country. Indonesian government realizes it. And the Research, Technology, and Higher Education Ministry started implementing a nation-wide program of lecturer certification with the aim to certify the lecturers in Indonesia. The ministry implemented some performance appraisal for certified lecturers.

There are some lecturers' performance appraisals in Indonesia, such as $\mathrm{BKD}$, it is a Lecturer's workload including a number of jobs that a lecturer should do as an institutional task and it represents a lecturers' responsibility in three main higher education activities [1],

\footnotetext{
*Corresponding Author: dyahayupuripalupi@gmail.com, mardanung@gmail.com
} 
SIPKD (Lecturer's Career Development Information System), it is a service for lecturers to report their activity every semester but it is under construction now (Research, Technology, and Higher Education Ministry, 2015) and SKP (Employee Job Target), it is the work plan and targets should be achieved by a civil servant. The SKP contains activities of official duties and targets should be achieved in the period of time in a measurable assessment [2]. $\mathrm{BKD}$ is only to evaluate the lecturers' performance based on the report and supporting data of the three main activities that the lecturers should do i.e. education, research, and community service. SIPKD assesses the performance based on the report and the supporting data of the three main activities by online. The three of the performance evaluation system have not included the assessment from students and peer review yet. Here is the existing performance appraisal (e.g. BKD/Lecturer's Workload):
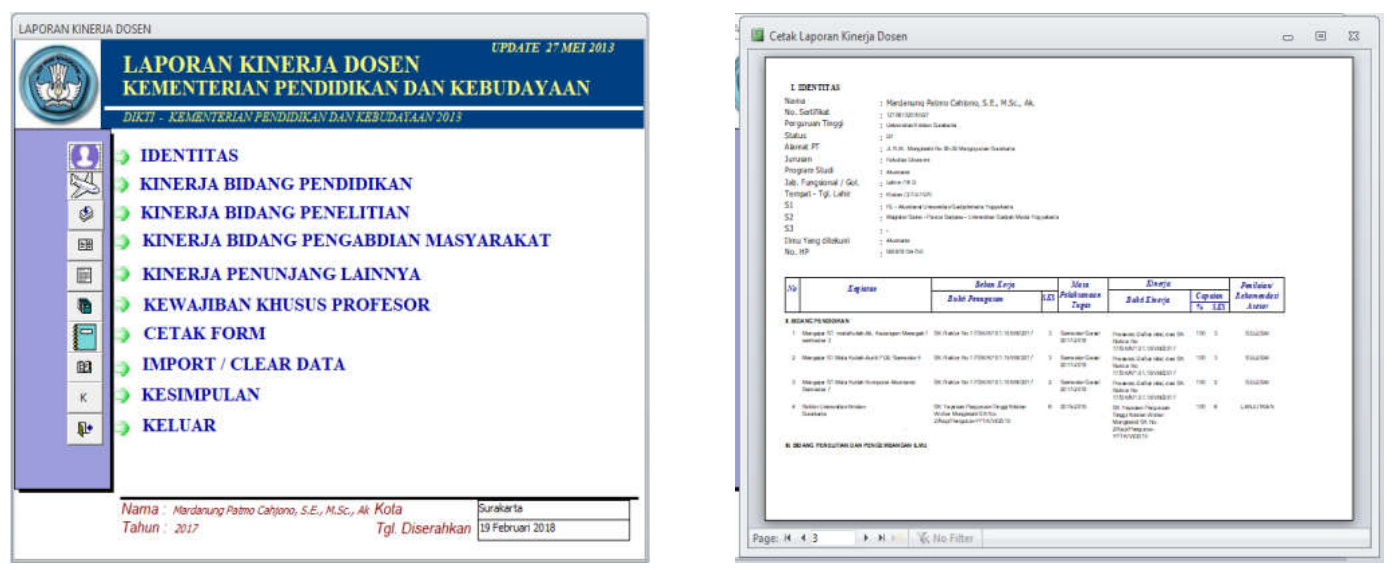

Fig. 1. BKD/ Lecturer's Workload

The fact, assessment from superior, peer, and students are really important. Because it shows the real assessment of the lecturer's character. A good lecturer is not only good at the three main activities (education, research, and community service) but also at their relationship with peer, students, and superior. So we proposed the performance appraisal model including 360 degrees evaluation, as followed:

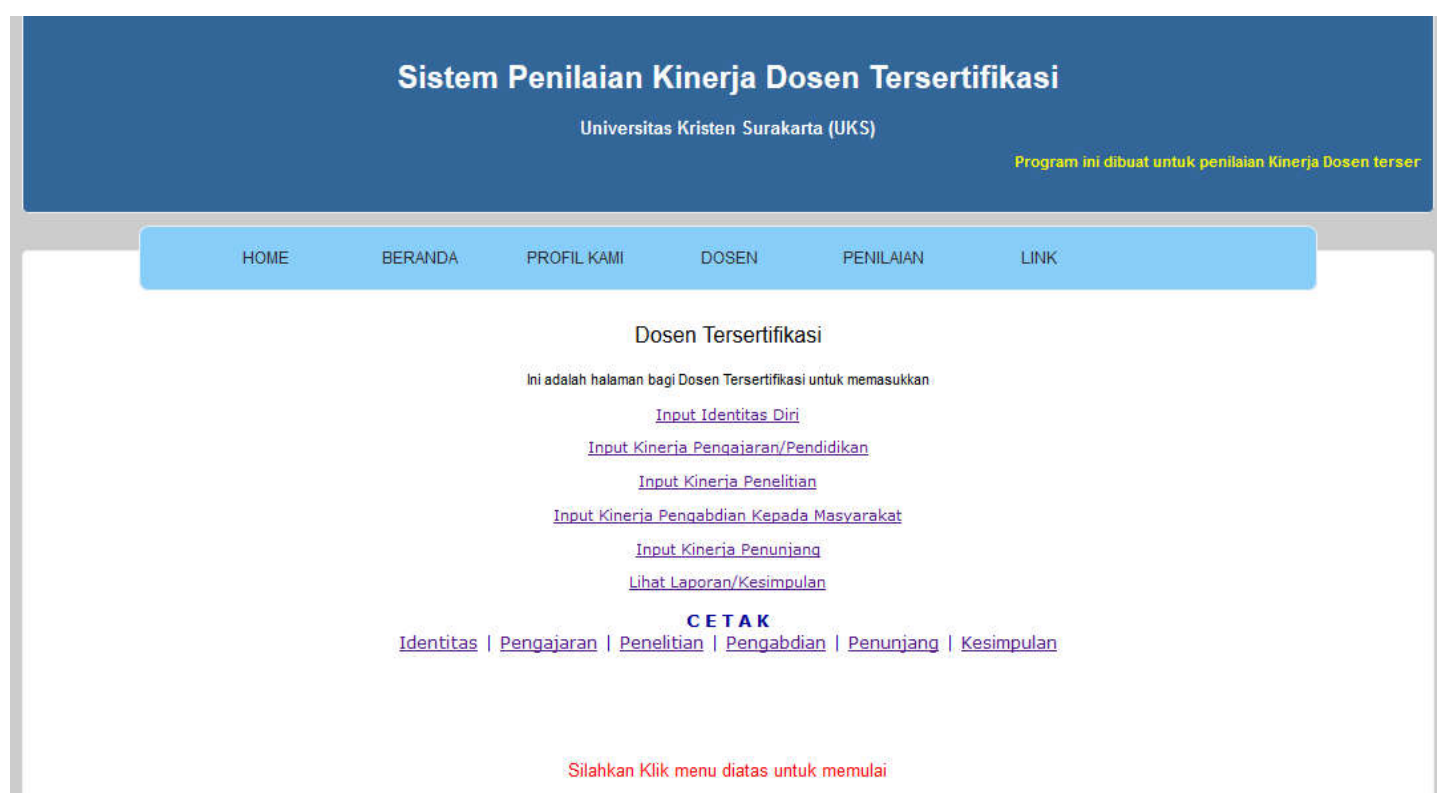




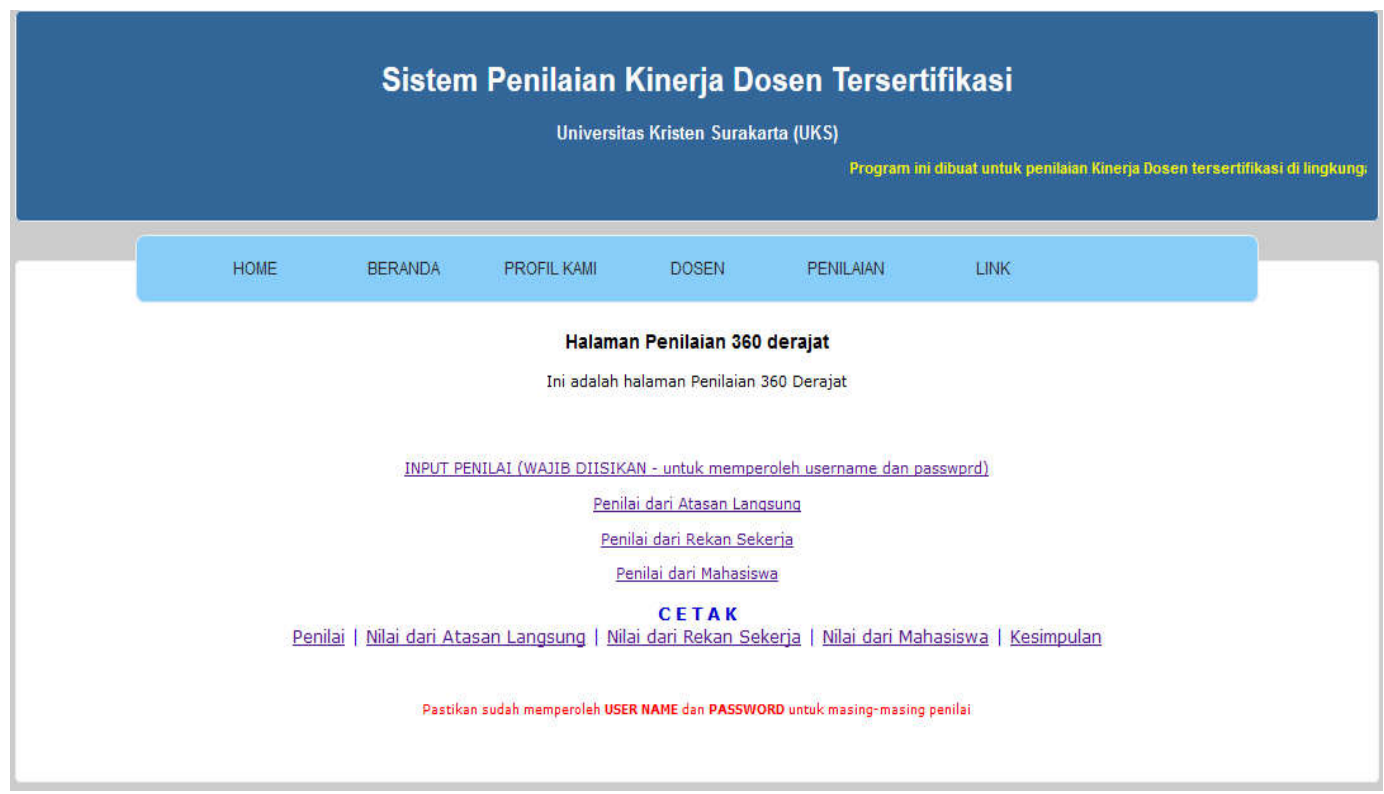

Fig. 2. Integrated Evaluation Model (IEM)

The provision of lecturer certification also still need more serious attention. According to Erlan Muliadi [3], from UIN SUKA Yogyakarta states that the certification policies that reap the pros and cons in society are still a warm conversation to talk about. Because the government policy of certification has a great influence for the direction of education in Indonesia and it is mainly related with lecturer performance after receiving certification compensation.

Certification is a proof that a lecturer has professionalism, integrity, high moral character and competitiveness. That is why the lecturers must have high integrity and moral. It is proved from their attitude to the peer, superior, and students.

\section{Theoretical Review}

\subsection{A 360-degree Performance Appraisal System}

In 360-degree appraisal system, information is obtained from several sources such as the boss, top management, assistants, co-workers, customers, dealers, advisors, and community officials. All these can be classified into internal and external parties [4]. It collects data from a variety of sources to accurately depict performance information and is a useful tool in identifying employee strengths and weaknesses. If the 360-degree appraisal is undertaken with its proper ground work, and in clear perspective it will work as a powerful tool for the performance management system [5].

\subsection{Performance}

Performance is the result of human behavior which is an important factor for evaluating individual work effectiveness [6]. Thus, the success or failure of an organization depends 
on the job performance of the individuals in that organization. Performance is an important factor for better enhancement of the organization.

Pujiwati [7] stated that performance assessment and career development is able to maintain the level of employee's commitment. Khan et.al [8] defined job performance as work performance in terms of quantity and quality expected from each employees (business dictionary).

\subsection{Certified Lecturers}

As stated in Law of Teachers and Lecturers Number 14 of 2005 regarding Teachers and Lecturers, lecturer is defined as a professional educator and scholar who have the main duty in transforming, developing, and disseminating knowledge, technology, and art through education, research, and community service. Professional is defined as a work or activity which is done and being an income source which requires skill and expertise which fulfill the quality standard or a particular norm and professional education. Certified lecturer is a lecturer who has earned credential from authorize source such as government. They have been given educator certification after they reported their self-description about their teaching qualification included a number of academic and professional degree [9].

\section{Result and Discussion}

\subsection{Integrated Evaluation Model (IEM) Indicators}

Based on the responses from the focused group discussion attended by 12 lecturers and 8 students, they are included languange expert, IT expert, and educational expert. The questionnaires indicators in the Integrated Evaluation Model (IEM) should be adjusted to the four competencies stated in the Law of teachers and lecturers Number 14 of 2005. The four competencies, namely pedagogic competence, professional competence, social competence, and personality competence. So we made some changes in the IEM questionnaires indicator. Before getting some suggestion from the FGD participant, we didn't include the four competencies.

Here are the questionnaires after getting some changes:

a. The questionnaire of superiors includes:

Pedagogic Competency

- Have relevant knowledge with the current position

- Accomplish the tasks given on time

- Able to communicate with the students well

\section{Social Competency}

- Consult the problems with the superiors

- Able to communicate with the community well

- Always provide an alternative solution for the problem encountered by institution

- Always provide good initiatives for the institution progress

\section{Professional Competency}

- Use the time effectively

- Arrive and leave the meeting on time

- Arrive at work on time

- Respond appropriately to feedback on job performance.

\section{Personality Competency}

- Respond feedback on critique and advice appropriately and quickly.

- Loyal to the institution 
- Obey the institution's rules and regulations

\section{b. The questionnaire of peer includes:}

Pedagogic Competency

- The evaluated lecturer gives the peer suggestions as to how they can improve their teaching

- The evaluated lecturer has knowledge and understanding of learning practices

Social Competency

- The evaluated lecturer provides a helping hand for the problem encountered by colleagues

- The evaluated lecturer often shares the information related to the learning activity and institution

- The evaluated lecturer has a willing to collaborate with study program members or with faculty members

- The evaluated lecturer works to establish and maintain a positive relationship with all colleagues

- The evaluated lecturer often participates in the formal and informal activities with the colleagues

\section{Professional Competency}

- The evaluated lecturer often has a positive communication discussion about improving learning process quality with colleagues

- The evaluated lecturer is not affected by personal business when he or she works at the office

\section{Personality Competency}

- The evaluated lecturer often avoids having conflict with colleagues

- The evaluated lecturer has a good character related with the interpersonal relationship

\section{c. The questionnaire of student includes:}

\section{Pedagogic Competency}

- The evaluated lecturer masters the learning material

- The evaluated lecturer has an ability to explain the subject clearly and systematically

- The evaluated lecturer is able to motivate the students to study harder

- The evaluated lecturer is willing and able to answer the students' questions in class

- The evaluated lecturer gives the lecturer based on the syllabus

\section{Social Competency}

- The evaluated lecturer is willing to help the students outside the class

- The evaluated lecturer has an objectivity in academic assessment

- The evaluated lecturer uses the learning facilities such as LCD and whiteboard

\section{Professional Competency}

- The evaluated lecturer explains the syllabus and learning contract in the first meeting

- The evaluated lecturer gives the instruction clearly on the assigned tasks

- The evaluated lecturer assigns tasks based on the learning material

- The evaluated lecturer gives test based on the learning material

- The students can get benefit from the material

\section{Personality Competency}

- The evaluated lecturer responds appropriately on critique and advice.

- The evaluated lecturer is able to control the emotion in class well 
The result of the validity and reliability test from the item above as followed:

Table 1. Validity and Reliability Output

\begin{tabular}{|l|c|c|c|c|c|c|c|c|c|}
\hline \multirow{2}{*}{$\begin{array}{c}\text { Compe } \\
\text { Tency }\end{array}$} & \multicolumn{3}{|c|}{ Superordinate appraisal } & \multicolumn{4}{c|}{ Peer review } & \multicolumn{3}{c|}{ Student evaluation } \\
\cline { 2 - 10 } & Item & $\begin{array}{c}\text { Validi } \\
\text { ty }\end{array}$ & $\begin{array}{c}\text { Cron. } \\
\text { Alpha }\end{array}$ & Item & $\begin{array}{c}\text { Validi } \\
\text { ty }\end{array}$ & $\begin{array}{c}\text { Cron. } \\
\text { Alpha }\end{array}$ & Item & $\begin{array}{c}\text { Validi } \\
\text { ty }\end{array}$ & $\begin{array}{c}\text { Cron. } \\
\text { Alpha }\end{array}$ \\
\hline Pedagogic & 3 & Valid & 0.845 & 1 & - & - & 6 & Valid & 0.793 \\
\hline Social & 6 & Valid & 0.783 & 6 & Valid & 0.787 & 3 & Valid & 0.821 \\
\hline Professional & 4 & Valid & 0.834 & 2 & Valid & 0.820 & 5 & Valid & 0.781 \\
\hline Personality & 3 & Valid & 0.814 & 2 & Valid & 0.822 & 2 & Valid & 0.589 \\
\hline
\end{tabular}

Source: data procressed

\subsection{Integrated Evaluation Model (IEM) Development}

The certified lecturer appraisal model includes:

- Administrative performance appraisal through BKD (Lecturer's workload). It consists of the assessment on education, research, community service, and supporting activities

- A 360 degrees performance appraisal, the evaluators are superior, peer, and students. The evaluators fill the questionnaires in the program. This is the novelty of the research.

The implementation of IEM on the certified lecturers showed a positive result. The students as the evaluator seemed satisfied because they could participate in evaluating their lecturers. The certified lecturers seemed satisfied too, because they were able to know their performance, not only in academic performance but also in social performance. The lecturers can get the performance appraisal result from IEM output as followed:

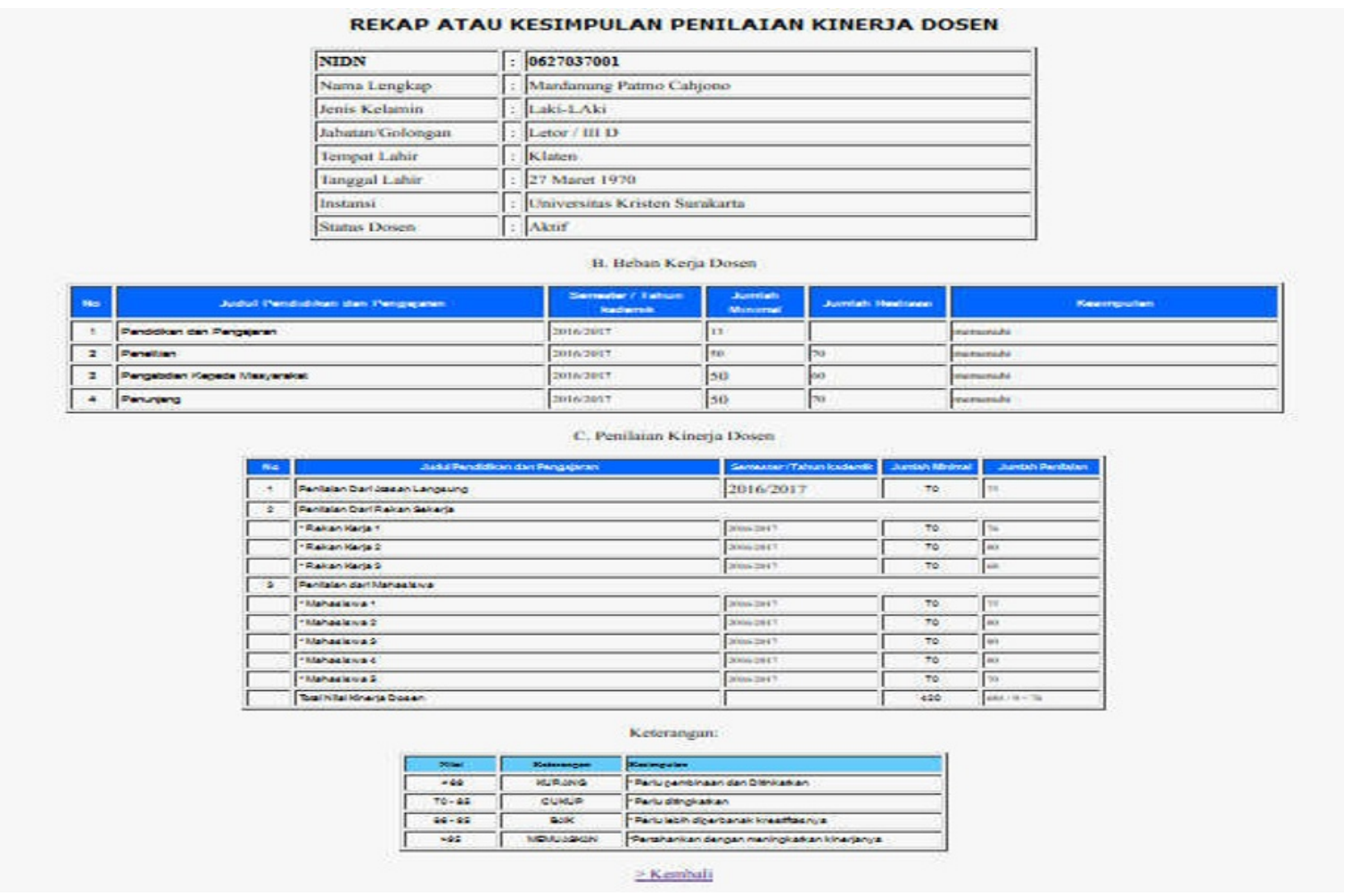

Fig. 3. IEM Output 


\section{Conclusion and Suggestion}

\subsection{Conclusion}

Based on the FGD results and according to the Law of teachers and Lecturers Number 14 of 2005, the certified lecturers performance appraisal indicators are grouped into four categories, namely pedagogic category, social category, professional category, and personality category. And IEM is an effective way to evaluate the certified lecturers' performance, because it doesn't only evaluate the academic performance but also the character of the certified lecturer. And it is the novelty of this research. Here is the IEM software:

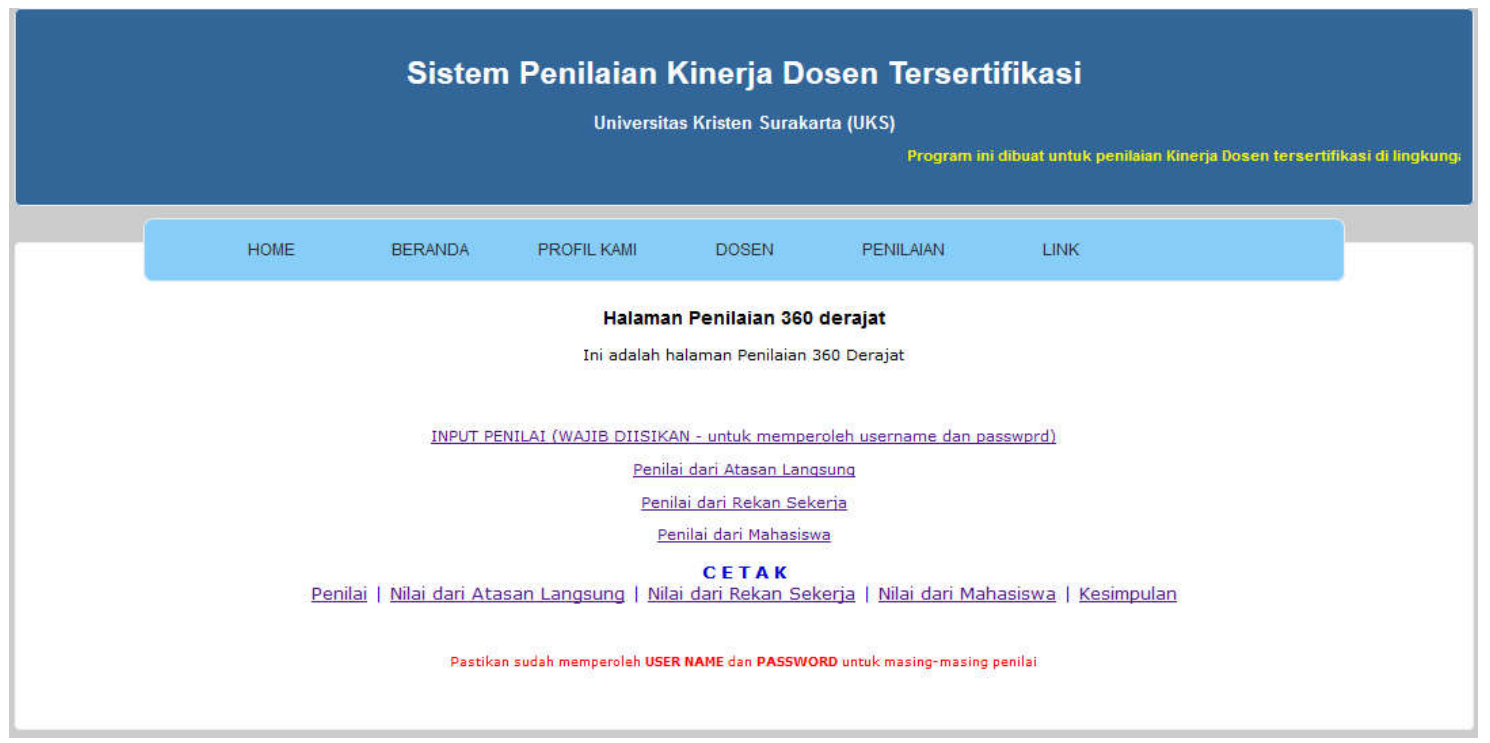

Fig. 4. IEM Software

\subsection{Limitation}

The limitation of this study is the respondent. They are the certified lecturers of Kopertis 6 Central Java only.

\subsection{Suggestion}

IEM could be implemented as the certified lecturers' performance appraisal nationally because it evaluates both academic performance and character of the certified lecturers.

\section{Acknowledgement}

I would like to express my special thanks of gratitude to Research, Technology, and Higher Education Ministry which funded us in doing this research via Applied Product Research in 2016-2017.

\section{References}

1. M. Adimihardja, Beban Tugas Dosen, Universitas Lampung (2010)

2. Regulation of Government number 46, 2011 
3. http://erlanmuliadi.blogspot.com/2011/04/kebijakan-sertifikasi-guru-dan-dosen.html, accessed on Tuesday, March, 12th 2013 at. 21.07

4. MI. Rasheed, HD. Aslam, S. Yousaf, and A. Noor,. A critical analysis of performance appraisal system for teachers in public sector universities of Pakistan: A case study of the Islamia University of Bahawalpur (IUB). Af J B M, 5, pp. 3735-3744, (2011).

5. T. Ragunadhan and AH. Sequiera,. Strategic 360 Degree Performance Appraisal Model as a Synergy for Strategic Education Planning in Premier HTIs in India. Am Int J R Hum, Arts and Soc Sci. (2013)

6. J. Saetang, K. Sulumnad, P. Thampitak, and T. Sungkaew,. Factors Affecting Perceived Job Performances among Staff :A Case Study of Ban Karuna Juvenile Vocational Training Centre for Boys, J B Sci, 5, 1, pp. 33 - 45 (2010)

7. A. Pujiwati, The Influence of Performance Assessment and Career Development on Employee's Commitment. RIBER, 5, 2, 175-185 (2016)

8. MR. Khan, Ziauddin, FA. Jam, M.I. Ramay,. The Impacts of Organizational Commitment on Employee Job Performance. Eur J. of S S. 15, 3, pp. 292-298. (2010)

9. Law of Teachers and Lecturers Number 14, 2005. 